\title{
Partitioning particulate light absorption: A budget for a Mediterranean bay
}

\author{
Carlos M. Duarte, Susana Agustí, and Maria Paola Satta \\ Centro de Estudios Avanzados de Blanes, CSIC, Camí de Santa Bárbara s/n, 17300 Blanes, Girona, Spain
}

\author{
Dolors Vaqué \\ Institut de Ciencies del Mar, CSIC, Avgda. Joan de Borbó s/n, Barcelona, Spain
}

\begin{abstract}
The contribution of different components of the plankton (autotrophs and heterotrophic bacteria, heterotrophic flagellates, and mixo- and heterotrophic ciliates) and suspended inorganic particles to light absorbed by particles in a Mediterranean bay was examined based on a 2-year time series of particulate light absorption (400-700, 400, and $675 \mathrm{~nm}$ ), the biomass of planktonic microorganisms, and the mass of suspended inorganic particles. The average $( \pm \mathrm{SE})$ particulate light absorption coefficient for the photosynthetically active radiation (PAR) range $(0.035 \pm 0.002$ $\mathrm{m}^{-1}$ ) was characteristic of relatively clear coastal waters but showed great variability on occasions. A substantial fraction (53-73\%, depending on the wavelength examined) of this variability could be accounted for by changes in the abundance of inorganic suspended matter, as well as planktonic organisms. The specific light absorption by autotrophs was less variable over the three spectral bands considered than those of microheterotrophs and inorganic particles, which dropped sharply with increasing wavelength. Inorganic particles contributed, on the average, 48 and $74 \%$ of the total particulate absorption for the PAR waveband and at $400 \mathrm{~nm}$, respectively, with their contribution to light absorption at $675 \mathrm{~nm}$ being negligible. Autotrophs dominated light absorption at $675 \mathrm{~nm}$ (on average $45.8 \%$ of total particulate absorption), whereas mixo- and heterotrophic ciliates and hacteria together contributed, on average, $22.5 \%$ of the total light absorption at this wavelength. The combined light absorption coefficient of microheterotrophs at $400 \mathrm{~nm}\left(0.0126 \mathrm{~m}^{-1}\right)$ was similar to that of autotrophs $\left(0.013 \mathrm{~m}^{-1}\right)$. These results documented the dominant role that inorganic particles play in the absorption of blue light in the Bay of Blanes and showed that the particulate light absorption by autotrophs was often comparable to that of heterotrophs.
\end{abstract}

Suspended particles play a major role in controlling the optical properties of the sea (e.g. Kirk 1983), particularly in coastal waters, which contain greater particulate loads, both organic and inorganic, than do oceanic ones. The study of light absorption by planktonic autotrophs has received particular attention as an essential process in the functioning of marine ecosystems. More recently, however, light absorption by heterotrophic planktonic organisms has been shown to be significant (Morel and Ahn 1990, 1991; Agustí 1994), leading to claims that these organisms must also be considered in examinations of the photon budget of the ocean (cf. Agustí 1994).

Photosynthetic pigments, dominated by $\mathrm{Chl} a$, allow autotrophic planktonic communities to have relatively high specific absorption coefficients in the blue and red bands (e.g. Kirk 1983). In contrast, the absorption spectra of inorganic particles, detritus, and heterotrophic organisms are characterized by high absorption coefficients in the blue region of the visible spectrum, where they have specific (i.e. per unit mass or volume) absorption coefficients close to those of phytoplankton (cf Agustí 1994), and by a sharp decline in

\section{Acknowledgments}

This research was funded by projects MAR91-0503 and AMB940746 of the Spanish Interministerial Commission for Research and Technology (CICYT) and project PhaSE (contract MAS3-CT960053) of the European Commission. We gratefully acknowledge the Comisió Interministerial de Cienci i Tecnologia (CIRIT, grant GRQ93-80-42). We thank the Ciencia members of the "plankton" group in Blanes that helped along the study, E. Benavent for assistance in preparing the figures, and T. Granata for helpful comments on the manuscript. absorption coefficients at longer wavelengths (e.g. Morel and Ahn 1990, 1991; Agustí 1994). Inorganic particles often dominate the pool of suspended particles, particularly in shallow coastal waters (e.g. Monaco et al. 1990; Dauby et al. 1995), where the biomass of heterotrophic organisms often exceeds that of autotrophs (e.g. Gasol et al. 1997). Hence, light absorption by inorganic particles and heterotrophic microplankton can equal (or exceed) that by photosynthetic plankton, particularly at the blue end of the visible spectra (cf. Agustí 1994).

The light absorbed by planktonic autotrophs can be derived from the bulk light absorption coefficients measured on particles collected on filters using algorithms developed to deconvolute the absorption spectra (cf. Morrow et al. 1989; Bricaud and Stramski 1990) or by measuring particulate light absorption before and after extraction of photosynthetic pigments (Kishino et al. 1985). These approaches have allowed the partition of the particulate light absorption between an autotrophic and nonautotrophic components (e.g. Iturriaga and Siegel 1989; Morrow et al. 1989; Bricaud and Stramski 1990; Agustí and Cruzado 1992; Allali et al. 1995). The nonautotrophic component comprises a wide array of particles, including detritus, microheterotrophs, and inorganic particles. However, there is as yet no reliable approach to partition the light absorption by nonautotrophic particles into different components. Present knowledge on the light absorption of planktonic heterotrophs is derived from measurements on cultured bacteria and protists (Morel and Ahn 1990,1991 ) and metazoans isolated in the laboratory (Agustí 1994), which may not be directly extrapolatable to natural marine communities. As a consequence, there are major dif- 
ficulties in the partitioning of the light absorption by photosynthetic organisms, heterotrophic microorganisms, detritus, and inorganic particles.

Here we examine the contribution of different components of the plankton (autotrophs and heterotrophic bacteria, flagellates, and mixo- and heterotrophic ciliates) and suspended inorganic particles to light absorbed by particles in a Mediterranean bay (Bay of Blanes, NE Spain). We do so based on a 2-year time series of particulate light absorption, the biomass of planktonic autotrophs and heterotrophic bacteria, flagellates, and mixo- and heterotrophic ciliates, and the mass of suspended inorganic particles. The planktonic communities of the Mediterranean littoral zone are characterized by a high abundance of microheterotrophs (Vaqué 1996; Vaqué et al. 1997), while inorganic particles often comprise a substantial fraction (typically $\sim 70 \%$ ) of the suspended particle load of coastal Mediterranean waters (e.g. Monaco et al. 1990; Dauby et al. 1995). We therefore hypothesize that inorganic particles and heterotrophic organisms must be responsible for a sizable fraction of the particulate light absorption coefficient in littoral Mediterranean waters, comparable to or exceeding that of planktonic autotrophs.

\section{Methods}

Subsurface water samples were collected at a fixed station ( $15 \mathrm{~m}$ deep) in the Bay of Blanes $\left(41^{\circ} 39.90^{\prime} \mathrm{N}, 2^{\circ} 48.03^{\prime} \mathrm{E}\right)$ twice a week from March 1992 to March 1993 and once a week from March 1993 to March 1994. Sampling frequency was increased (to 1 or $0.5 \mathrm{~d}^{-1}$ ) during phytoplankton blooms. Surface water was collected from an outboard motor boat with clean 5-liter bottles and kept refrigerated while transported to the laboratory (within $30 \mathrm{~min}$ ). At the laboratory, a variable water volume $(50-500 \mathrm{ml}$, depending on phytoplankton biomass) was filtered through Whatman GF/F filters for fluorometric analysis of $\mathrm{Chl} a$ concentration (Parsons et al. 1984). The filters were homogenized and kept refrigerated in the dark while pigments were extracted in $90 \%$ acetone for $\sim 6 \mathrm{~h}$. Fluorescence was measured, following extraction, in a Turner Designs fluorometer calibrated with pure Chl $a$ (Sigma). Total seston concentration and inorganic seston concentration were estimated from the dry weight (24 $\mathrm{h}$ at $\left.80^{\circ} \mathrm{C}\right)$ and ash content $\left(24 \mathrm{~h}\right.$ at $\left.440^{\circ} \mathrm{C}\right)$ of seston collected by filtering between 1 and 2 liters of water through preweighed GF/F filters. Planktonic organisms also contribute to the ash content of seston, but, provided that the ash content of seston typically exceeded $70 \%$ of its dry mass, this contribution must be $<5 \%$ of the total ash content.

The abundances of heterotrophic bacteria and nanoflagellates were determined by epifluorescence microscopy and that of ciliates by using an inverted microscope. Duplicate water samples for bacteria and nanoflagellates were preserved with formaldehyde $(0.5 \%$ final concn $)$ and glutaraldehyde ( $1 \%$ final concn), respectively, and stained with 4,6diamidino-2-phenylindole (DAPI; Porter and Feig 1980). A $100-\mathrm{ml}$ sample was preserved in a $1 \%$ final concentration of Lugol's solution for enumeration of ciliates (autotrophic, mixotrophic, and heterotrophic). Ciliates were counted after settling with an inverted microscope at $200 \times$ magnification.
Bacterial biovolume was determined with an epifluorescence microscope, measuring the length and width of 20 cells from 10 samples. Protist biovolume was calculated from cell length and width of at least 20 cells per sample hy approximation to the nearest geometric figure.

Light absorption by suspended particles was measured on particles collected on filters following Mitchell and Kiefer (1988). Seston was concentrated by filtering a variable volume of water (1-2.5 liters, depending on suspended sediment concentration) through $2.5-\mathrm{cm}$ Whatman GF/F filters. Light absorption by particles concentrated on the filters was measured immediately after collection. The optical density of the filters $\left(\mathrm{OD}_{\mathrm{f}}\right)$ was measured in dual-beam scanning spectrophotometers (Shimadzu UV-2100 and JASCO-UV 7800) using a clean-water-saturated Whatman GF/F filter as a blank. $\mathrm{OD}_{\mathrm{f}}$ was measured at $1-\mathrm{nm}$ intervals between 380 and $750 \mathrm{~nm}$.

Particle light absorption $\left(a_{p}, \mathrm{~m}^{1}\right)$ was calculated as

$$
a_{p}(\lambda)=2.3 \mathrm{OD}_{i}(\lambda) C / V \beta(\lambda) \text {, }
$$

where $\lambda$ is the wavelength (nm), 2.3 is the factor to convert base-10 logarithms to natural logarithms, $C$ is the clearance area of the filter $\left(\mathrm{m}^{2}\right), V$ is the volume of seawater filtered $\left(\mathrm{m}^{3}\right)$, and $\beta$ is the wavelength-dependent pathlength amplification factor of the filters, calculated after Bricaud and Stramski (1990). For descriptive purposes, the absorption spectra obtained $(>200)$ were summarized by computing mean and standard deviation spectra at 5-nm intervals for each month of the year. To illustrate how the partitioning of the particulate light absorption coefficient differs with the wavelength considered, we focused on the average particulate light absorption for the photosynthetically active radiation (PAR range, $400-700 \mathrm{~nm}$ ), those at the 675-nm absorption peak of Chl $a$, and the 400-nm wavelength, where all suspended particles considered here strongly absorb.

To partition the particulate light absorption coefficients obtained, we first computed the average light absorption coefficient per unit mass or biovolume for each of the components considered using least-squares multiple linear regression. This analysis regressed each of the particulate light absorption coefficients examined ( $a_{p}(\mathrm{PAR}), a_{p}(400 \mathrm{~nm})$, $a_{p}(675 \mathrm{~nm})$, units of $\left.\mathrm{m}^{-1}\right)$ against the concentration of $\mathrm{Chl}$ $a\left(\mathrm{mg} \mathrm{m}^{-3}\right)$, as an estimate of the biomass of autotrophic plankton, the biovolume of heterotrophic bacteria, flagellates, and mixo- and heterotrophic ciliates $(B, F$, and $C$, respectively, units of $10^{9} \mu \mathrm{m}^{3} \mathrm{~m}^{-3}$ ), and the mass of inorganic material $\left(I, \mathrm{~g} \mathrm{~m}^{-3}\right)$ using equations of the form

$$
\begin{aligned}
& a_{p(\mathrm{PAR})}, a_{p(440 \mathrm{~mm})} \text {, or } a_{p(675 \mathrm{~nm})}\left(\mathrm{m}^{-1}\right) \\
& =a+a_{p}{ }^{*}{ }_{(\mathrm{Chl}())} \text { Chl } a+a_{p}{ }^{*}(B) B
\end{aligned}
$$

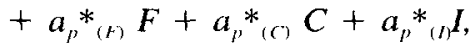

where the coefficients $a_{p}{ }^{*}$ provide estimates of the average spccific absorption cocfficient per unit $\mathrm{Chl} a$, heterotroph biovolume, or inorganic particle weight, and the coefficient $a$ represents the average residual absorption coefficient contributed by particles other than those comprised in the independent terms of the equation. Provided that the concentration of the different components of the suspended particle pool were independent (Pearson correlation analysis, $P>$ 0.05 ), this statistical approach yields unbiased estimates of 

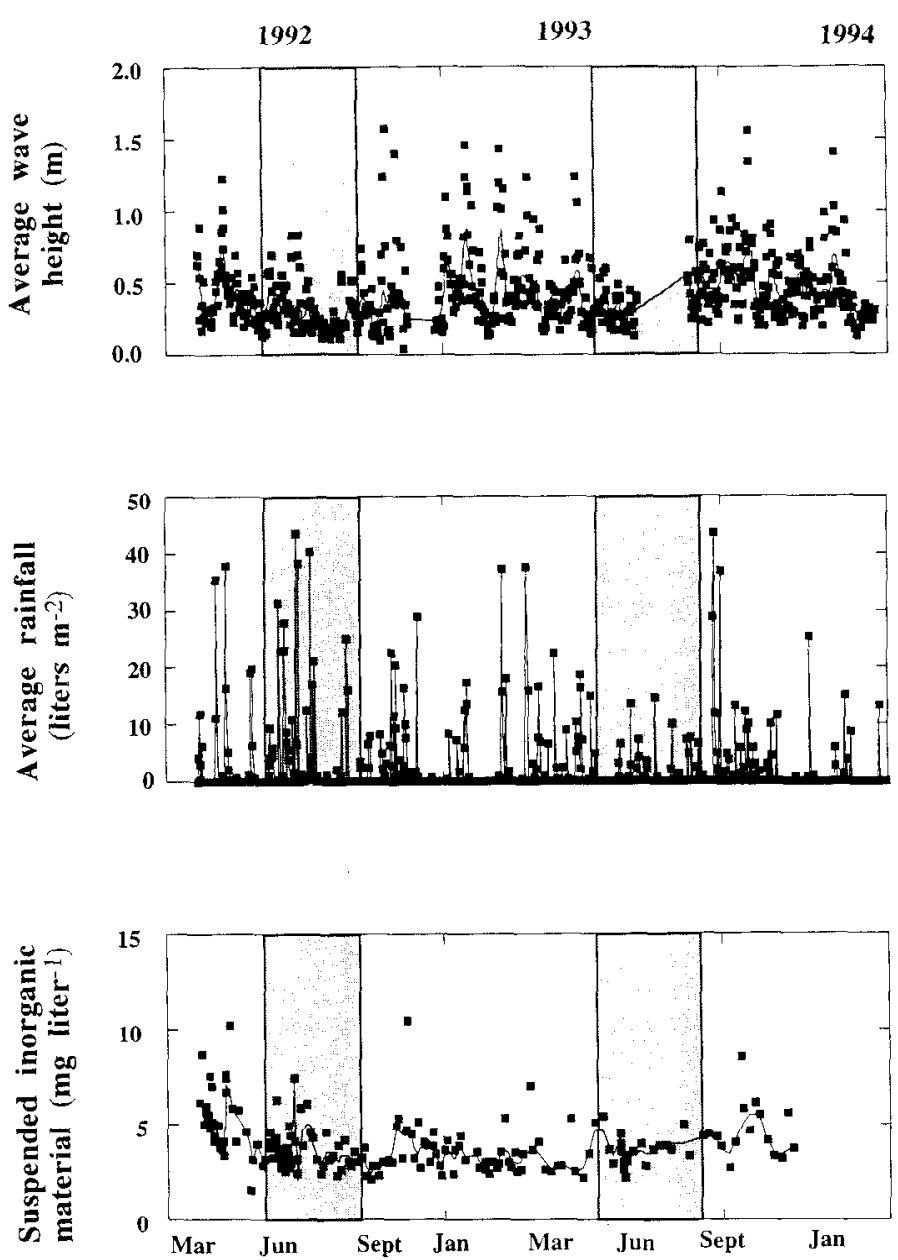

Fig. 1. Daily average wave height, daily rainfall, and seston concentration between March 1992 and March 1994 in the Bay of Blanes. Shaded areas represent the periods of stratified waters (water temperature $>20^{\circ} \mathrm{C}$ ), and continuous lines represent a running average.

the average specific absortion coefficients. The estimates of the biovolume of ciliates $(C)$ included that of heterotrophic as well as mixotrophic ciliates. Mixotrophic ciliates (dominated by the genera Tontonia and Laboea; Vaqué 1996; Vaqúe et al. 1997) were combined with the heterotrophic ciliates because they derive their chloroplasts from those of the algae they ingest (i.e. through grazing activity; Stoecker et al. 1987; Laval-Peuto 1992; Bernard and Rassoulzadegan 1994).

The contribution of each of the components to the total particulate light absorption coefficient measured during the time series was estimated as the product between their concentration and the average specific absorption coefficients, estimated as described above. Because the specific absorption coefficients derived from the procedures outlined above represent average estimates, we examined the contribution of the different components considered to light absorption by first averaging the data by months.

\section{Results}

Wave action could be very substantial, with daily average wave height reaching about $1.5(\max .3-4) \mathrm{m}$ during strong
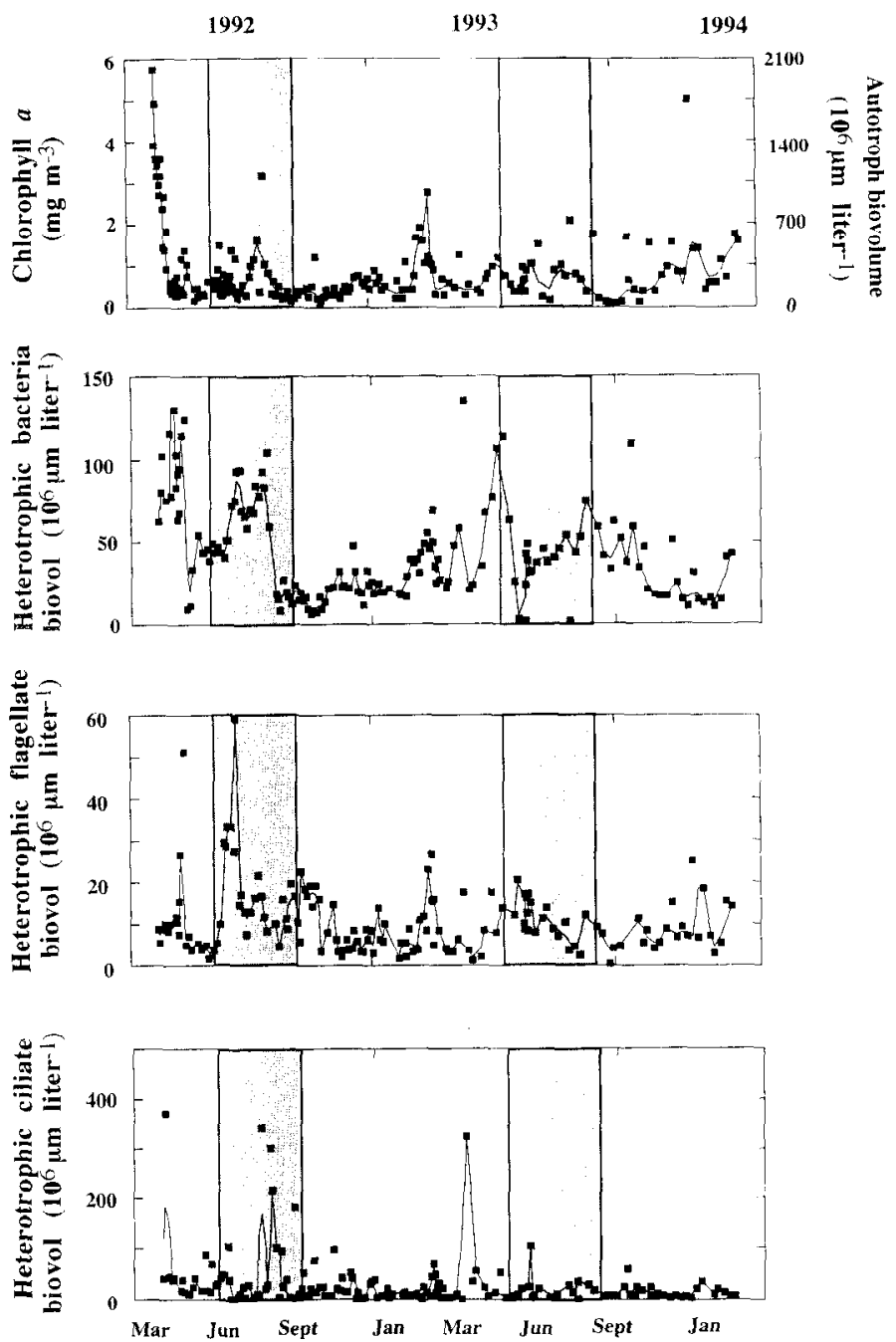

Fig. 2. Chl a concentration (and equivalent biovolume of autotrophs) and the biovolume of heterotrophic bacteria, heterotrophic flagellates, and heterotrophic and mixotrophic ciliates between March 1992 and March 1994 in the plankton of the Bay of Blanes. Shaded areas represent the periods of stratified waters (water temperature $>20^{\circ} \mathrm{C}$ ), and continuous lines represent a running average.

wave events (Fig. 1). Wave action was reduced during the stratified season, which was preceded and followed by periods of strong wave action (Fig. 1). Rainfall showed a rather skewed distribution, characteristic of the Mediterranean climate, and a contrasting pattern between 1992, which was the wettest summer in 30 years, and 1993, with a more characteristic dry summer (Fig. 1). Both wave action and rainfall influenced the suspended particle load in the bay, as indicated by significant direct positive correlations $(P<0.005)$ between maximum daily wave height and daily rainfall and total particulate load. Most of the suspended particle mass corresponded to inorganic particles (mean $\pm \mathrm{SE}=74 \pm$ $0.49 \%$ by weight), their concentration ranging between 2 and $10 \mathrm{mg} \mathrm{liter}{ }^{-1}$ (Fig. 1), depending on wave height and rainfall.

Chl $a$ concentrations were gencrally $<1 \mathrm{mg} \mathrm{Chl} a \mathrm{~m}^{3}$ and varied between $<0.1$ and $5.7 \mathrm{mg} \mathrm{Chl} a \mathrm{~m}^{-3}$ (March 1992, Fig. 2). Phytoplankton blooms were generally observed in late winter (early March) and summer (July), al- 
Table 1. Particulate light absorption (mean \pm SE, and range) at different wavelengths $(\lambda)$ and its partitioning into different components (NS, = nonsignificant [below detection limit]).

\begin{tabular}{lcccc}
\hline \hline $\begin{array}{c}\text { Particulate absorption } \\
\left(\mathrm{m}^{\prime}\right)\end{array}$ & $\begin{array}{c}\lambda \\
(\mathrm{nm})\end{array}$ & Mean $\pm \mathrm{SE}$ & Range & $\%$ total \\
\hline Total & PAR & $0.035 \pm 0.002$ & $0.008-0.416$ & - \\
& 675 & $0.024 \pm 0.001$ & $0.003-0.159$ & - \\
Inorganic particles & 400 & $0.083 \pm 0.007$ & $0.016-1.324$ & - \\
& PAR & $0.017 \pm 0.0004$ & $0.006-0.044$ & 48 \\
& 675 & $\mathrm{NS}$ & $\mathrm{NS}$ & 0 \\
Autotrophs & 400 & $0.062 \pm 0.00$ & $0.024-0.164$ & 74 \\
& PAR & $0.010 \pm 0.0007$ & $0.001-0.068$ & 28.5 \\
& 675 & $0.011 \pm 0.0008$ & $0.001-0.073$ & 45.8 \\
Heterotrophic bacteria & 400 & $0.013 \pm 0.0009$ & $0.001-0.084$ & 15.6 \\
& PAR & $0.0004 \pm 0.00002$ & $0.0002-0.019$ & 1.1 \\
Heterotrophic flagellates & 675 & $0.0030 \pm 0.0001$ & $0.0001-0.009$ & 12.5 \\
& 400 & $0.0017 \pm 0.0001$ & $0.0001-0.005$ & 2.0 \\
& PAR & $0.0034 \pm 0.0002$ & $0.0002-0.0189$ & 9.7 \\
Heterotrophic and & 675 & $\mathrm{NS}$ & $\mathrm{NS}$ & 0 \\
mixotrophic ciliates & 400 & $0.0064 \pm 0.0004$ & $0.0004-0.035$ & 7.7 \\
& PAR & $0.0016 \pm 0.0004$ & $0.00003-0.052$ & 4.6 \\
\hline
\end{tabular}

though these blooms differed greatly in magnitude (Fig. 2). Isolated Chl $a$ maxima (e.g. $5 \mathrm{mg} \mathrm{Chl} a \mathrm{~m}^{-3}$ on 6 January 1994) also occurred as a result of resuspension of microphytobenthos following strong gales. The biovolume of bacteria and heterotrophic flagellates also showed great temporal variability, with high bacterial abundance preceding and following the onset of summer stratification. The biovolume of heterotrophic flagellates showed no apparent seasonality, but tended to be greater during the first year studied (Fig. 2). The biovolume of mixo- and heterotrophic ciliates showed a remarkable homogeneity, interrupted by sudden, isolated bursts (Fig. 2), apparently associated with maxima in flagellate biomass. The abundance of the different groups of microplanktonic organisms considered varied independently of each other $(P>0.05)$. Similarly, there was no significant $(P>0.05)$ correlation between changes in Chl $a$ concentration and those in the biovolume of microheterotrophs, which was also uncoupled of changes in phytoplankton community structure (cf. Mura et al. 1996).

The average light absorption coefficient for the PAR range $\left(0.035 \pm 0.002 \mathrm{~m}^{-1}\right)$ was characteristic of relatively clear coastal waters, with the average absorption coefficient at 400 $\mathrm{nm}$ being more than twofold greater than those for the PAR range and $675 \mathrm{~nm}$ (Table 1). Particulate absorption spectra were characterized by high absorption in the blue band and a peak at $675 \mathrm{~nm}$, due to absorption by Chl $a$ (Fig. 3). The variability in particulate absorption within months showed a similar spectral pattern characterized by higher variation in the blue wavelengths (Fig 3). The shape of the average absorption spectra was closer to that of Chl $a$ during March, May and July, while that observed in January, which was the month with the highest variation in particulate absorption coefficients, showed little influence of Chl $a$ and suggested a high load of suspended sediments (Fig. 3). There was little evidence of a contribution of photosynthetic pigments other than Chl $a$ to particulate light absorption, which was only suggested by the average absorption spectra observed in August, the time when the abundance of the cyanobacteria Synechococcus sp. is greatest (Mura et al. 1996).

The variability in the particulate light absorption coefficient showed no consistent difference between periods with stratified and mixed water columns at any of the wavelengths examined (Fig. 4). The variability in the particulate absorption coefficient was closely correlated with the abundance of inorganic suspended matter, as well as with that of planktonic organisms (Table 2). These relationships were described using multiple linear regression analyses, which showed the variability in the abundance of these particles to account for $57-73 \%$ of the variance in the particulate absorption coefficients, depending on the wavelengths considered (Table 2).

The coefficients of the multiple regression equations describing particulate light absorption as a function of the abundance of different components of the pool of suspended particles provided estimates of their average specific light absorption coefficients at the different wavelengths considered (Table 2). These estimates were rather robust, as indicated by the small standard errors about the mean estimates (Table 2). In general, the specific light absorption coefficients were greatest in the blue region (e.g. $400 \mathrm{~nm}$ ) and lowest at $675 \mathrm{~nm}$, with the average specific absorption coefficients over the PAR range having intermediate values (Table 2). The specific light absorption by autotrophs was less variable over the three spectral bands considered than those of microheterotrophs and inorganic particles. The specific absorption coefficients of microheterotrophs and inorganic particles dropped sharply with increasing wavelength, with the specific absorption at $675 \mathrm{~nm}$ not differing significantly from zero for both inorganic particles and heterotrophic flagellates.

The average specific absorption coefficients derived for each component allowed, when combined with the observed 

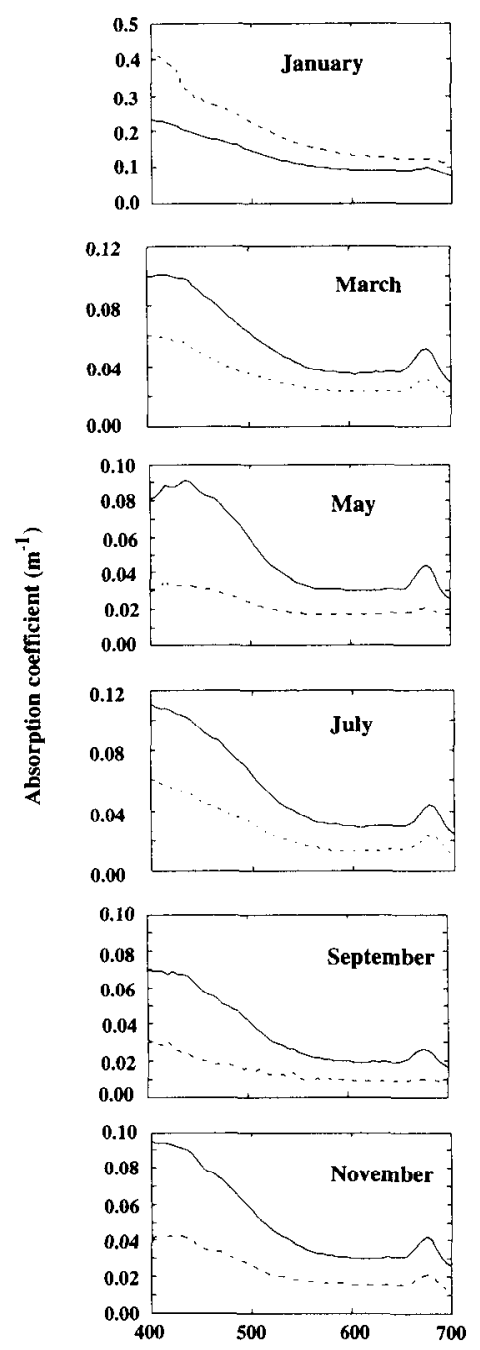

Wavelength $(\mathbf{n m})$
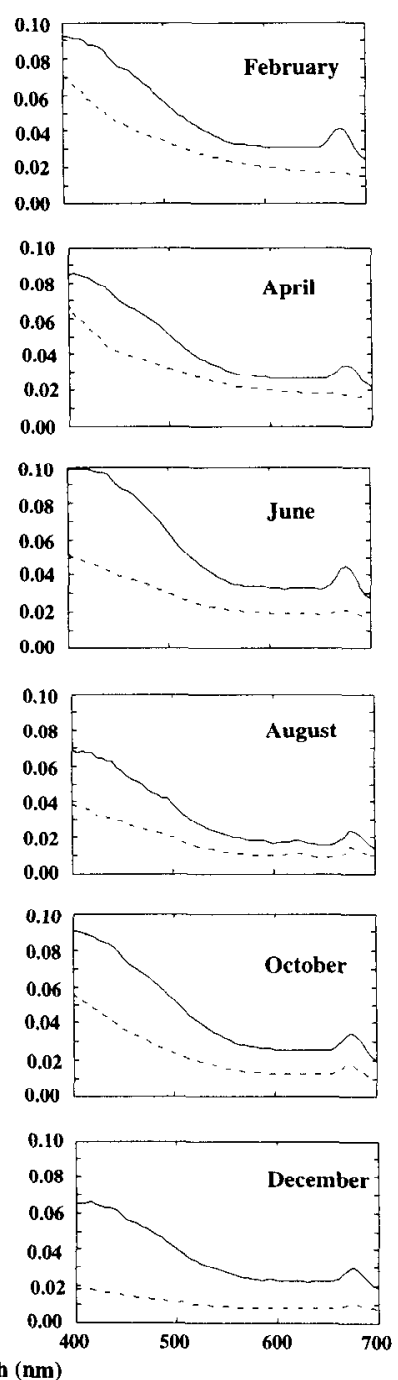

Fig. 3. Average (- - ) and standard deviation (-- ) monthly particulate light absorption spectra in the Bay of Blanes. The spectra were computed after pooling together all of the spectra obtained for each month, independently of the year when they were obtained.

abundances during the 2-year time series, calculation of the average percentage of the light absorbed by each of these components. These calculations reveal that light absorption by inorganic particles dominated the total particulate absorption at $400 \mathrm{~nm}$ and the average PAR band, where they contributed, on average, 74 and $48 \%$ of the total particulate absorption, respectively (Table 1). The contribution of inorganic particles to light absorption at $675 \mathrm{~nm}$, however, was negligible. Autotrophs dominated light absorption at $675 \mathrm{~nm}$ (on average $45.8 \%$ of total particulate absorption) whereas mixo- and heterotrophic ciliates and bacteria together contributed, on average, $22.5 \%$ of the total light absorption at this wavelength. Furthermore, the combined percent light absorbed by microheterotrophs at $400 \mathrm{~nm}$ was similar to that of autotrophs (Table 1). Examination of the temporal variability in the partitioning of the light absorption among planktonic organisms clearly shows that both heterotrophic and autotrophic organisms acted as major components of
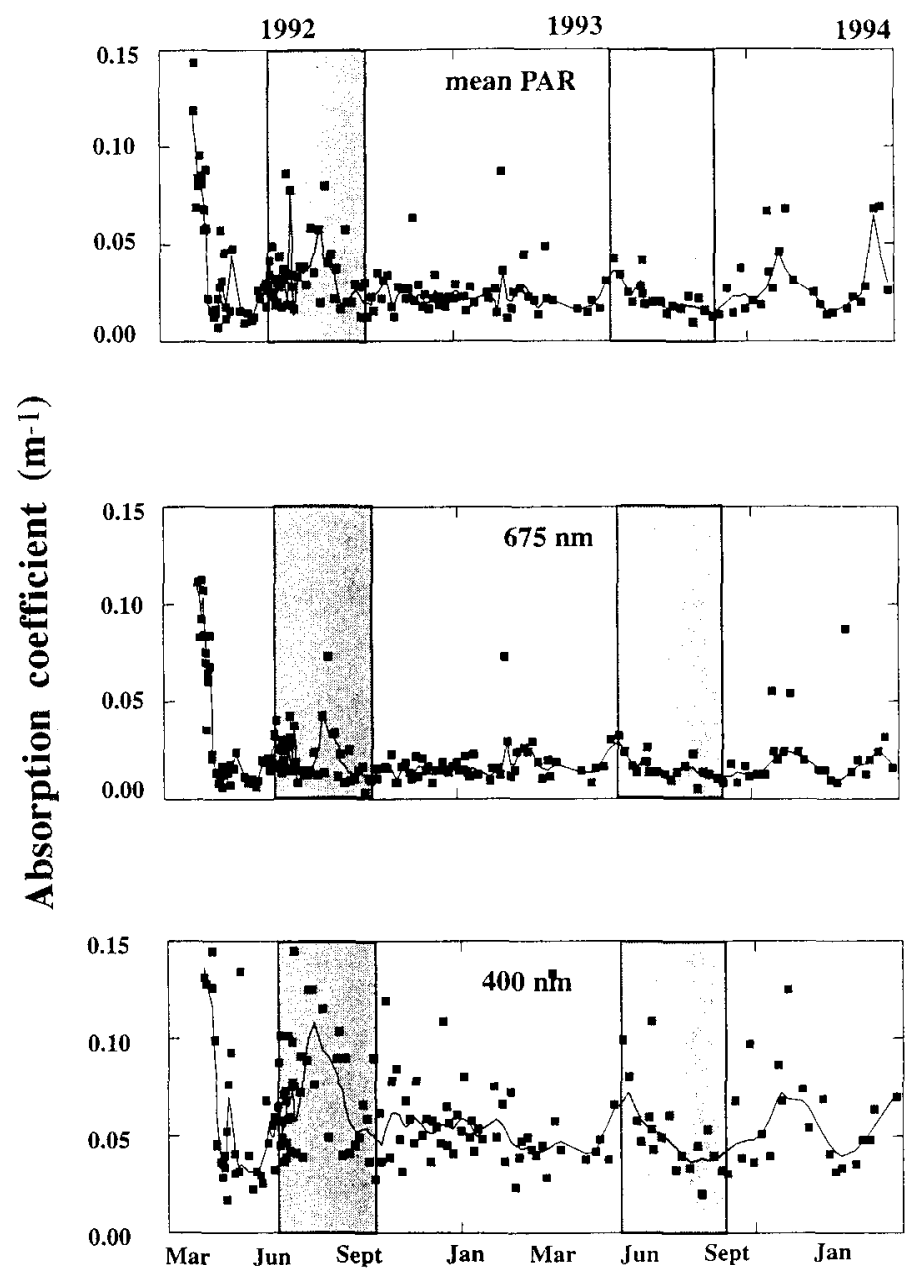

Fig. 4. Particulate light absorption coefficient (PAR mean, 675 $\mathrm{nm}$, and $400 \mathrm{~nm}$ ), between March 1992 and March 1994 in the waters of the Bay of Blanes. Shaded areas represent the periods of stratified waters (water temperature $>20^{\circ} \mathrm{C}$ ), and continuous lines represent a running average.

biological light absorption (Fig. 5). Autotrophs typically absorbed 40-50\% of the biological light absorption both for the average PAR band and at $675 \mathrm{~nm}$ (Fig. 5). In contrast, heterotrophs were the dominant components of the light absorbed by the biotic component at $400 \mathrm{~nm}$, at which autotrophs only absorbed $20 \%$ on average, of the total light absorbed by the biogenic component of the seston (Figs. 5, 6). In general, light absorption by heterotrophs was relatively more important in 1992, particularly between the initiation of the study (March 1992) and September 1992, a period coincident with blooms of these heterotrophic organism (Figs. 2, 4).

\section{Discussion}

The results presented document the importance of both biological components and inorganic particles for the particulate light absorption in the Bay of Blanes. This bay has relatively clear waters (mean \pm SE light extinction coefficient of $0.11 \pm 0.02 \mathrm{~m}^{-1}, N=9$; Duarte unpubl. data), 
Table 2. Multiple linear regression estimates of the specific (per unit mass or biovolume) light absorption coefficients (mean \pm SE for PAR mean, $675 \mathrm{~nm}$, and $400 \mathrm{~nm}$ ) for different components (inorganic particles, autotrophs, and heterotrophic bacteria, flagellates, and heterotrophic and mixotrophic ciliates) of the suspended matter in the Bay of Blanes. The regression statistics are summarized by the coefficients of determination $\left(R^{2}\right)$ and the $F$-ratio. (NS, $P>0.05 ; *, 0.001<P<0.05$; **, $P<0.001$ ).

\begin{tabular}{|c|c|c|c|c|}
\hline $\begin{array}{r}W_{v} \\
(\mathrm{~nm})\end{array}$ & Component (units) & Specific coefficient & $R^{2}$ & $F$ \\
\hline \multirow[t]{5}{*}{ PAR } & Inorganic $\left(\mathrm{m}^{2} \mathrm{~g}^{-1}\right)$ & $0.0043 \pm 0.001 * *$ & 0.64 & $39.3 * *$ \\
\hline & Autotrophs $\left(\mathrm{m}^{2} \mathrm{mg} \mathrm{Chl} a^{-1}\right)$ & $0.0119 \pm 0.002 * *$ & & \\
\hline & Heterotrophic bacteria $\left(\mathrm{m}^{2}\left(10^{9} \mu \mathrm{m}^{3}\right)^{-1}\right)$ & $0.00005 \pm 0.00002 *$ & & \\
\hline & Heterotrophic flagellates $\left(\mathrm{m}^{2}\left(10^{9} \mu \mathrm{m}^{3}\right)^{-1}\right)$ & $0.00003 \pm 0.0001^{*}$ & & \\
\hline & Heterotrophic/mixotrophic ciliates $\left(\mathrm{m}^{2}\left(10^{9} \mu \mathrm{m}^{3}\right)^{-1}\right)$ & $0.00004 \pm 0.00001 * *$ & & \\
\hline \multirow[t]{5}{*}{675} & Inorganic $\left(\mathrm{m}^{2} \mathrm{~g}^{-1}\right)$ & $0.0003 \pm 0.0007 \mathrm{NS}$ & 0.74 & $60.7 * *$ \\
\hline & Autotrophs $\left(\mathrm{m}^{2} \mathrm{mg} \mathrm{Chl} a^{-1}\right)$ & $0.0127 \pm 0.002 * *$ & & \\
\hline & Heterotrophic bacteria $\left(\mathrm{m}^{2}\left(10^{9} \mu \mathrm{m}^{3}\right)^{-1}\right)$ & $0.00007 \pm 0.00003 *$ & & \\
\hline & Heterotrophic flagellates $\left(\mathrm{m}^{2}\left(10^{9} \mu \mathrm{m}^{3}\right)^{-1}\right)$ & $0.00001 \pm 0.0001 \mathrm{NS}$ & & \\
\hline & Heterotrophic/mixotrophic ciliates $\left(\mathrm{m}^{2}\left(10^{9} \mu \mathrm{m}^{3}\right)^{-1}\right)$ & $0.00006 \pm 0.00001^{* *}$ & & \\
\hline \multirow[t]{5}{*}{400} & Inorganic $\left(\mathrm{m}^{2} \mathrm{~g}^{-1}\right)$ & $0.016 \pm 0.002 * *$ & 0.58 & $30.3 * *$ \\
\hline & Autotrophs $\left(\mathrm{m}^{2} \mathrm{mg} \mathrm{Chl} a^{-1}\right)$ & $0.0146 \pm 0.006 * *$ & & \\
\hline & Heterotrophic bacteria $\left(\mathrm{m}^{2}\left(10^{9} \mu \mathrm{m}^{3}\right)^{-1}\right)$ & $0.0001 \pm 0.00004^{*}$ & & \\
\hline & Heterotrophic flagellates $\left(\mathrm{m}^{2}\left(10^{9} \mu \mathrm{m}^{3}\right)^{-1}\right)$ & $0.0006 \pm 0.0003^{*}$ & & \\
\hline & Heterotrophic/mixotrophic ciliates $\left(\mathrm{m}^{2}\left(10^{9} \mu \mathrm{m}^{3}\right)^{-1}\right)$ & $0.0001 \pm 0.00003^{* *}$ & & \\
\hline
\end{tabular}

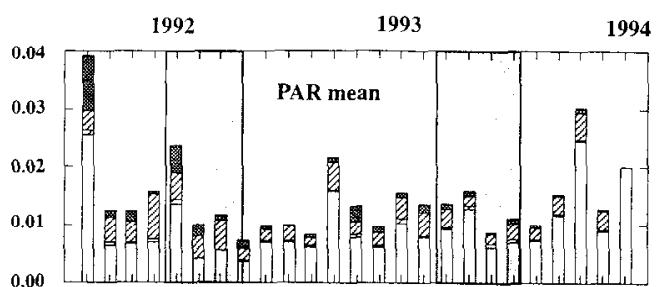

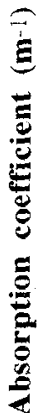
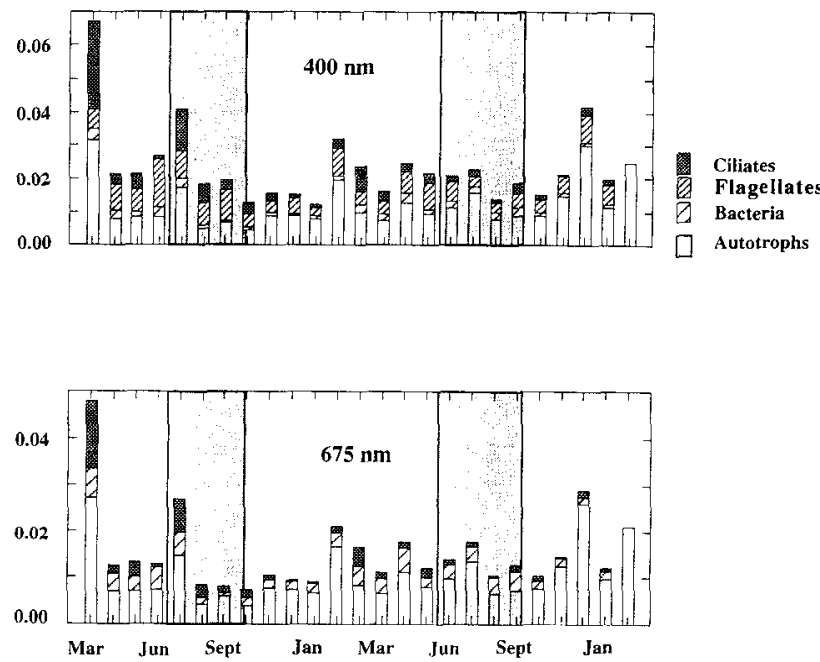

Fig. 5. The contribution of different components of the plankton (autotroph and heterotrohic bacteria, flagellates, and heterotrophic and mixotrophic ciliates) to the light absorption coefficient (PAR mean, $675 \mathrm{~nm}$, and $400 \mathrm{~nm}$ ) in the Bay of Blanes. Shaded areas represent the periods of stratified waters (surface seawater temperature $>20^{\circ} \mathrm{C}$ ).
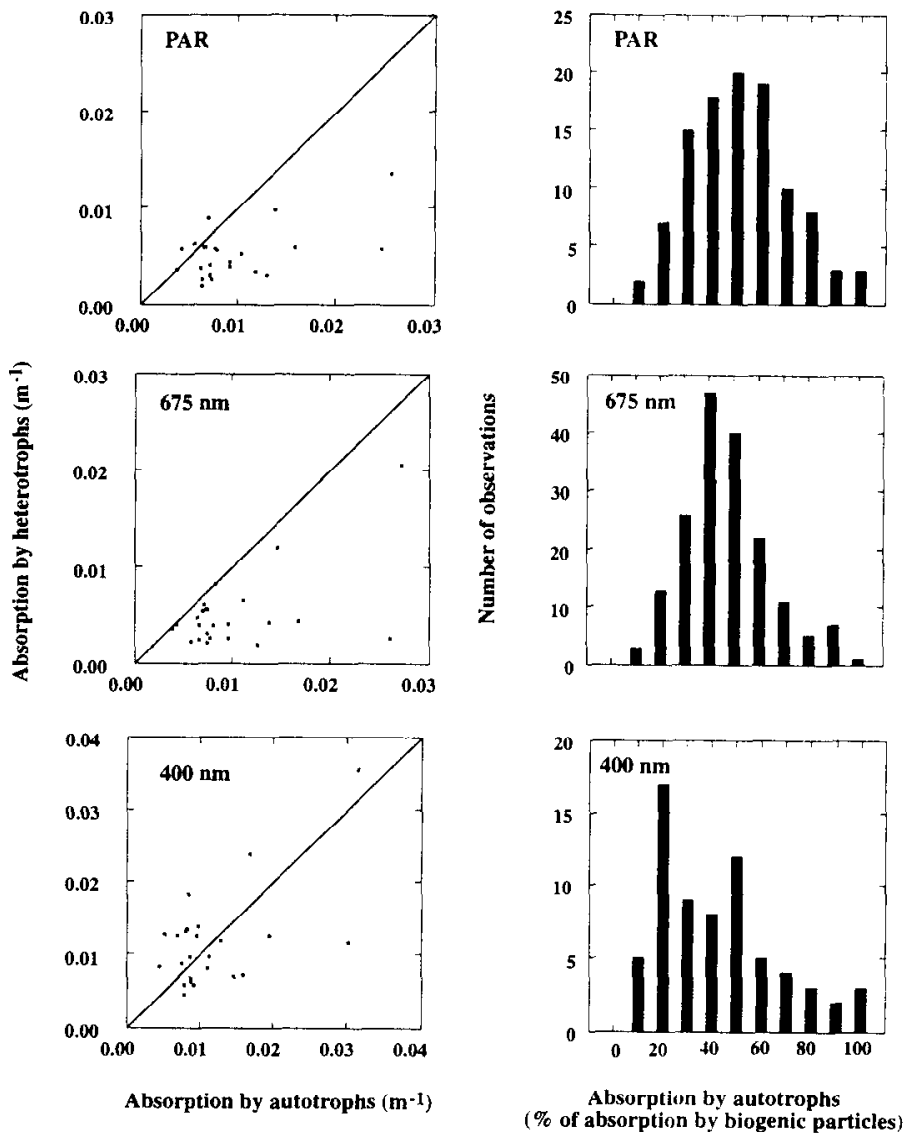

Fig. 6. The relationship between the light absorption coefficient (monthly averages) of planktonic autotrophs and microheterotrophs in the Bay of Blanes, and the frequency distribution of the percentage of light absorption coefficient of microplanktonic organisms contributed by autotrophs for the PAR range, and at 675 and 400 $\mathrm{nm}$. The solid lines in the scatter plots represent the $1: 1$ line. 
characteristic of the NE Spanish Mediterranean coast. The particulate light absorption coefficients measured in this study are somewhat higher than those reported for other, clearer Mediterranean bays (Allali et al. 1995), but are similar to those reported by Agustí and Cruzado (1992) for the Gulf of Lions (average at $675 \mathrm{~nm}$ of $0.02 \mathrm{~m}^{-1}$; table 1 in Agustí and Cruzado 1992).

In the blue region of the spectrum, the particulate light absorption coefficient was dominated by contributions from inorganic particles (48 and $74 \%$ of particulate light absorption for the average PAR range and at $400 \mathrm{~nm}$, respectively). The light absorption spectra of inorganic particles are characterized by a sharp exponential decline with increasing wavelength to reach very low values in the red band of the PAR spectrum (Kirk 1983). The dominant role of inorganic particles in the particulate light absorption is consistent with their dominant contribution to the total suspended particle mass in the Bay of Blanes, consistent with previous reports of particle flux in the coastal NW Mediterranean (Monaco et al. 1990; Dauby et al. 1995). The origin of this inorganic matter must be diverse, comprising both materials discharged from rivers, resuspended from the bottom, and biogenic inorganic materials (e.g. Monaco et al. 1990). The correlation between the mass of inorganic particles, wave height, and rainfall in the Bay of Blanes suggests, however, that these particles resulted largely from resuspension of sediments and sediment delivery by nearby rivers during heavy rainfall.

The light absorption coefficient attributable to phytoplankton represents $45.8 \%$ of the average total particulate absorption at $675 \mathrm{~nm}$. The average absorption coefficient attributable to phytoplankton at $675 \mathrm{~nm}\left(0.011 \pm 0.0008 \mathrm{~m}^{-1}\right)$ was, however, much smaller than the absorption coefficient of pure water at this wavelength (about $0.44 \mathrm{~m}^{-1}$, Smith and Baker 1981), so that biological absorption was a minor component of the total photon loss at this wavelength as well (cf. Smith et al. 1989). The results obtained also suggest a greater contribution of inorganic particles and microheterotrophs to light absorption in the first year of the time series. The spring and early summer of 1992 were characterized by unusually heavy rainfall, which must have increased sediment delivery to the waters of the Bay of Blanes. The discharge of organic matter from rivers also stimulated heterotrophic growth (Vaqué 1996), resulting in a net heterotrophic community during that period (Satta et al. 1996).

The relatively low phytoplankton biomass found in the Bay of Blanes (mean $0.85 \pm 0.11 \mathrm{mg} \mathrm{Chl} a \mathrm{~m}^{-3}$; cf. Mura et al. 1996) explains the observation that light absorption by autotrophs did not dominate biological light absorption. The average specific absorption coefficient $(675 \mathrm{~nm})$ estimated for planktonic autotrophs in the Bay of Blanes $\left(a_{p}{ }^{*}{ }_{675}(\mathrm{Chl}\right.$ a) $=0.0127 \pm 0.002 \mathrm{~m}^{2}[\mathrm{mg} \mathrm{Chl} a]^{-1}$, Table 2) indicates a high degree of pigment packaging (cf. Kirk 1983). Moreover, the average specific absorption coefficient estimated for planktonic autotrophs is within the range of values reported for phytoplankton cultures and natural marine communities studied elsewhere (cf. table I in Iturriaga and Siegel 1989), supporting the adequate performance of the statistical method used to derive the specific absorption coefficients for the different components of the suspended particulate pool in the Bay of Blanes.

The biomass of heterotrophic microorganisms was similar to that of autotrophs in the Bay of Blanes (mean ratio of heterotrophic to autotrophic biovolume in the microplankton $=0.85 \pm 0.06$ ). This explains the significant role of heterotrophic microorganisms in the absorption of light by suspended particles in the Bay of Blanes. This observation is consistent with previous measurements in the Mediterranean, which reported a significant contribution of biogenic particles other than phytoplankton to light absorption (e.g. Agustí and Cruzado 1992; Allali et al. 1995). The contribution of planktonic microheterotrophs is particularly important in the blue region of the spectrum (Table 1), where heterotrophs have an absorption maximum (e.g. Morel and Ahn 1990, 1991). Estimates of specific light absorption coefficients per unit biovolume of microheterotrophs are still very limited and derived from cultured organisms (Morel and Ahn 1990, 1991; Agusti 1994). The available estimates are, however, comparable to those reported here, with our estimate of the PAR-average specific light absorption coefficient of bacteria $\left(0.00005 \mathrm{~m}^{2}\left[10^{9} \mu \mathrm{m}^{3}\right]^{-1}\right.$, Table 2$)$ being quite close to that $\left(0.000035 \mathrm{~m}^{2}\left[10^{9} \mu \mathrm{m}^{3}\right]^{-1}\right)$ recalculated from the data reported by Morel and Ahn (1990). Our estimate of the PARaverage specific light absorption coefficient of ciliates $\left(0.00004 \mathrm{~m}^{2}\left(10^{9} \mu \mathrm{m}^{3}\right)^{-1}\right.$, Table 2) was close, albeit somewhat greater than the value of $0.000014 \mathrm{~m}^{2}\left(10^{9} \mu \mathrm{m}^{3}\right)$ ' recalculated from the data reported by Morel and $\Lambda \mathrm{hn}$ (1991). This difference may be attributable to the fact that the ciliates in the study by Morel and Ahn (1991) were growing on heterotrophic prey, whereas ciliates have been shown to be major grazers of autotrophs in the NW Mediterranean Sea (Dolan and Marrasé 1995). Grazing on autotrophs allows ciliates to acquire photosynthetic pigments, which some retain to grow mixotrophically (Stoecker et al. 1987; LavalPeuto 1987). Indeed, mixotrophic ciliates can contribute a substantial proportion of the ciliate biomass in the NW Mediterranean littoral zone, particularly in the summer (Bernard and Rassoulzadegan 1994; Vaqué et al. 1997). The presence of intracellular pigments increases light absorption by ciliates at $\mathrm{Chl}$ a absorption peaks, as indicated by the fact that their specific absorption at $675 \mathrm{~nm}$ was somewhat greater than that averaged over the PAR waveband (Table 2). We cxpccted the intercept $(a)$ of the multiple regression equations to provide an estimate of average light absorbed by detrital particles. Regression intercepts, however, were not significantly different from zero, suggesting that the light absorbed by detrital particles may be generally low and partially included with that estimated to be absorbed by heterotrophic microorganisms. Microscopic observations show that detrital particles in the Bay of Blanes are not high compared to those of living planktonic microheterotrophs and autotrophs (Duarte unpubl. obs.). In addition, detrital particles are sites of very active heterotrophic activity (Fenchel 1970; Sorokin 1981), and their biomass is expected to be correlated to that of detritus.

The partitioning of the light absorption coefficient into that attributable to different components of the seston pool accounted for $58 \%$ (at $400 \mathrm{~nm}$ ) to $74 \%$ (at $675 \mathrm{~nm}$ ) of the variance in the bulk particulate light absorption coefficient. 
The unexplained variance may result from (1) error in the estimation of the concentration of different components of the seston, which is likely to exceed that in the bulk particulate light absorption coefficient; (2) temporal variability in the specific light absorption coefficients of the components considered; and (3) variability in the absorption by components of the seston not included in this study. The sources of variability in the specific light absorption coefficient of planktonic microheterotrophs are not yet well understood, while those for planktonic autotrophs include changes in growth conditions (Stramski and Morel 1990; Nielsen and Sakshaug 1993) and changes in community structure, such as changes in cell size (Agustí 1991) and accessory pigment complements of the dominant taxa (Sathyendranath et al. 1987; Hopeffner and Sathyendranath 1991, 1992). The phytoplankton community in the Bay of Blanes was dominated by diatoms, with an important contribution of cyanobacteria (Synechococcus spp.) in the summer (Mura et al. 1996). The importance of cyanobacteria in the summer could lead to an increase in the specific absorption coefficient of autotrophs, which is strongly size dependent (Agustí 1991), further enhanced by the contribution of accessory photosynthetic pigments, which can have a particularly important effect in light absorption by cyanobacteria (cf. Agustí 1991). Examination of absorption spectra (Fig. 3), however, yields no evidence of an important contribution of cyanobacteria accessory pigments to the total particulate light absorption. Moreover, the variance in the bulk particulate absorption coefficient unexplained by the multiple regression analyses was greatest at $400 \mathrm{~nm}$ and smallest at $675 \mathrm{~nm}$. This suggests that variability in the abundance of components that absorb strongly at 400 $\mathrm{nm}$, such as organic detritus, may have been an important source of variation. Future attempts at partitioning particulate light absorption may therefore improve by consideration of detritus when using recently available methods to quantify their abundance (Williams et al. 1995).

The results of this study document the important role of microheterotrophs in controlling the optical properties of the Bay of Blanes, in agreement with previous reports of an important contribution of microheterotrophs to the optical properties of seawater (Cho and Azam 1990; Morel and Ahn 1990, 1991; Agustí 1994). This role may be even more important in oligotrophic systems where the biomass of the microheterotrophs often equals or exceeds that of autotrophs (Bird and Kalff 1984; Cole et al. 1988; Fuhrman et al. 1989; Cho and Azam 1990; Simon et al. 1992; Gasol et al. 1997). As a result, the dynamics of the community of microplankton is imprinted in the optical properties of seawater (Spinrad et al. 1989; Stramski et al. 1992). Moreover, the observation that the light absorbed by autotrophs and heterotrophs reflects their relative biomass and metabolism (Agustí and Cruzado 1992) led to the postulate that the role of these organisms in the absorption of photons should be related to the flow of carbon (Agustí 1994). Hence, large contributions of microheterotrophs to total absorption by planktonic organisms in the Bay of Blanes are consistent with reports that the planktonic compartment of the Bay of Blanes tends to be net heterotrophic (Satta et al. 1996).

In summary, the partitioning of the particulate light absorption coefficient into different components demonstrated the dominant role that inorganic particles play in the absorption of blue light in the Bay of Blanes. The statistical approach used here to partition the particulate light absorption coefficient into different components yielded specific light absorption coefficients for planktonic organisms well in agreement with those reported in the literature. Although the particulate absorption in the red band is dominated by planktonic organisms, their compound coefficient was still much less than that for pure water. In addition, the light absorption by autotrophs was comparable to that by microheterotrophs, consistent with their important contribution to the mass and metabolism of microplankton in the Bay of Blanes. These results indicate that autotrophs face an important competition for light by inorganic particles and microheterotrophs even in relatively clear waters and provide a first step toward the elucidation of the photon budget of the Mediterranean littoral.

\section{References}

Agusti, S. 1991. Allometric scaling of light absorption and scattering by phytoplankton cells. Can. J. Fish. Aquat. Sci. 48: $763-767$

. 1994. Planktonic size structure and the photon budget of the euphotic ocean. In J. Rodríguez and W. K. W. Li [eds.], The size structure and metabolism of the pelagic ecosystem. Sci. Mar. 58: 109-117.

—_, AND A. CRuzado. 1992. Relationship between light absorption by pelagic particles and microplankton metabolic activity in the Gulf of Lions. Mar. Ecol. Prog. Ser. 85: 283-287.

Allali, K., A. Bricaud, M. Babin, and A. Mokill. 1995. A new method for measuring spectral absorption coefficients of marine particles. Limnol. Oceanogr. 40: 1526-1532.

BERNARD, C., AND F. RassoulzadEGAN. 1994. Seasonal variations of mixotrophic ciliates in the northwest Mediterranean Sea. Mar. Ecol. Prog. Ser. 108: 295-301.

BIRD, D. F., AND J. KALFF. 1984. Empirical relationships between bacterial abundance and chlorophyll concentration in fresh and marine waters. Can. J. Fish. Aquat. Sci. 41: 1015-1023.

BriCAud, A., AND D. STramski. 1990. Spectral absorption coefficients of living phytoplankton and non-algal biogenous matter: A comparison between the Peru upwelling area and the Sargasso Sea. Limnol. Oceanogr. 35: 562-582.

Cho, B. C., ANd F. Aடam. 1990. Biogeochemical significance of bacterial biomass in the ocean's euphotic zone. Mar. Ecol. Prog. Ser. 63: 253-259.

Cole, J. J., S. Findlay, AND M. L. Pace. 1988. Bacterial production in fresh and saltwaters: A cross system overview. Mar. Ecol. Prog. Ser. 43: 1-10.

DAUBY, P., AND OTHERS. 1995. Particle fluxes over a Mediterranean seagrass bed: A one year study. Mar. Ecol. Prog. Ser. 126: 233246.

Dolan, J. R., AND C. Marrasé. 1995. Planktonic ciliate distribution relative to a deep chlorophyll maximum: Catalan Sea, NW Mediterranean, June 1993. Deep-Sea Res. 42: 1965-1987.

FENCHEL, T. 1970. Studies on decomposition of organic detritus derived from turtlegrass. Limnol. Oceanogr. 15: 14-20.

Fuhrman, J. A., T. D. Sleeter, C. A. Carlson, and T. L. ProCTOR. 1989. Dominance of bacterial biomass in the Sargasso sea and its ecological implications. Mar. Ecol. Prog. Ser. 57: $207-217$

Gasol, J. M., P. D. DEl Giorgio, AND C. M. Duakte. 1997. Biomass distribution in marine planktonic communities. Limnol. Oceanogr. 42: 1353-1363. 
HoEPFFner, N., AND S. SATHYENDRANATH. 1991. Effect of pigment composition on absorption properties of phytoplankton. Mar. Ecol. Prog. Ser. 73: 11-23.

- AND - 1992. Bio-optical characteristics of coastal waters: Absorption spectra of phytoplankton and pigment distribution in the western North Atlantic. Limnol. Oceanogr. 37: $1660-1679$.

Itirriaga, R., AND D. A. Siegel. 1989. Microphotometric characterisation of phytoplankton and detrital absorption properties in the Sargasso Sea. Limnol. Oceanogr. 34: 1706-1726.

KIRK, J. T. O. 1983. Light and photosynthesis in aquatic ecosystems. Cambridge.

Kishino, M., M. Takahashi, N. Okami, and S. IChimura. 1985. Estimation of the spectral absorption coefficients of phytoplankton in the sea. Bull. Mar. Sci. 37: 634-642.

Laval-Peuto, M. 1992. Plastidic protozoa, p. 471-499. In W. Resisser [ed.], Algae and symbiosis. Biopress.

MrtcheI_L, B. G., AND D. A. KIFFFr. 1988. Chlorophyll $a$ specific absorption and fluorescence excitation spectra for phytoplankton. Deep-Sea Res. 35: 639-663.

Monaco, A., T. Courp, S. Heussner, J. Carbonne, S. W. Fowler, AND B. DeniauX. 1990. Seasonality and composition of particulate fluxes during ECOMARGE-I, western Gulf of Iions Continental Shelf Res. 10: 959-987.

Morel, A., AND Y.-H. AHN. 1990. Optical efficiency factors of free-living bacteria: Influence of bacterioplankton upon the optical properties and particulate organic carbon in oceanic waters. J. Mar. Res. 48: 145-175.

— AND - 1991. Optics of heterotrophic nanoflagellates and ciliates: A tentative assessment of their scattering role in oceanic waters compared to those of bacterial and algal cells. J. Mar. Res. 49: 177-202.

Morrow, J. H., W. S. Chamberlin, And D. A. Kiefer. 1989. A two-component description of spectral absorption by marine particles. Limnol. Oceanogr. 34: 1500-1509.

Mura, M. P., S. Agustí, J. Cebrián, And M. P. Satta. 1996. Seasonal variability of phytoplankton biomass and composition in Blanes Bay (1992-1994), p. 23-29. In C. M. Duarte [ed.], Seasonality in Blanes Bay: A paradigm of the northwest Mediterranean littoral. Publicaciones Especiales IEO No. 22, Instituto Español de Oceanografía.

Nielsen, M. V., and E. Sakshaug. 1993. Photobiological studies of Skeletonema costatum adapted to spectrally different light regimes. Limnol. Oceanogr. 38: 1576-1581.

Parsons, T. R., Y. MAITA, AND C. M. LALli. 1984. A manual of chemical and biological methods for seawater analysis. Pergamon.

Porter, K. G., And Y. S. FEIG. 1980. The use of DAPI for iden- tifying and counting aquatic microflora. Limnol. Oceanogr. 25: 943-948.

Sathyendranath, S., L. Lazzara, and L. Prieur, 1987. Variations in the spectral values of specific absorption of phytoplankton. Limnol. Oceanogr. 32: 403-415.

SatTA, M. P., S. Agustí, M. P. Mura, and C. M Dunrte. 1996. Microplankton respiration and net community metabolism in a bay on the N.W. Mediterranean coast. Aquat. Microb. Ecol. 10: $165-172$.

Simon, M., B. C. Cho, AND F. Azam. 1992. Significance of bacterial biomass in lakes and the ocean: comparison to phytoplankton biomass and biogeochemical implications. Mar. Ecol. Prog. Ser. 86: 103-110.

Smith, R. C., AND K. S. Baker. 1981. Optical properties of the clearest natural waters (200-800 nm). Appl. Optics 20: $177_{-}$ 184.

- , J. Marra, M. J. Perry, K. S. Baker, E. Swift, E. BusKEY, AND D. A. KIEFER. 1989. Estimation of a photon budget for the upper ocean in the Sargasso Sea. Limnol. Oceanogr. 34: 1673-1693.

SoROKIN, Y. I. 1981. Microheterotrophic organisms in marine ecosystems, p. 293-342. In A. R. Longhurst [ed.], Analysis of marine ecosystems. Academic.

SPINRAD, R. W., AND OTHERS. 1989. The response of beam attenuation to heterotrophic growth in a natural population of plankton. Limnol. Oceanogr. 34: 1601-1605.

Stoecker, D. K., A. E. Michaels, And L. H. Davies. 1987. A large fraction of marine planktonic ciliates can contain functional chloroplasts. Nature 326: 790-792.

STRAMSKI, D., AND A. MOREL. 1990. Optical properties of photosynthetic picoplankton in different physiological states as affected by growth irradiance. Deep-Sea Res. 37: 245-266.

, F. Rassoulzadegan, And D. A. Kiefer. 1992. Changes in the optical properties of a particle suspension caused by protist grazing. J. Plankton. Res. 14: 961-977.

VAQUÉ, D. 1996. Seasonal dynamics of planktonic microbial communities on the coast of the northwest Mediterranean Sea, p. 39-46. In C. M. Duarte [ed.], Seasonality in Blanes Bay: A paradigm of the northwest Mediterranean littoral. Publicaciones Especiales IEO No. 22, Instituto Español de Oceanografía.

- , H. A. Blough, And C. M. Duarte. 1997. Dynamics of ciliate biomass and community structure in an oligotrophic coastal environment (NW Mediterranean). Aquat. Microb. Ecol. 12: 71-83.

Williams, S. C., P. G. Verity, AND T. BeATtY. 1995. A new staining technique for dual identification of plankton and detritus in seawater. J. Plankton Res. 17: 2037-2047.

Received: 5 September 1996 Accepted: 19 May 1997 